\title{
Weight-gaining medications used by patients followed up at the bariatric and metabolic surgery service of a university hospital
}

\author{
Layse Antônio de SOUZA ${ }^{1}$ (D) , Allan Cezar ARAÚJO ${ }^{1}$ (D) , Ligiane de Lourdes da SILVA ${ }^{1}$, Poliana da Silva MENOLLI ${ }^{1}$ (i) \\ ${ }^{1}$ Universidade Estadual do Oeste do Paraná UNIOESTE, Cascavel,PR, Brasil. \\ Corresponding author: Menolli PS, polianacascavel@hotmail.com \\ Submitted: 21-03-2019 Resubmitted: 11-03-2020 Accepted: 12-03-2020 \\ Peer review: blind reviewers
}

\begin{abstract}
Objective: To verify an association between weight and use of medications that lead to weight gain (MLGP) in a population of obese patients monitored in the Unified Health System. Methods: This is a retrospective descriptive sectional study with data from medical records of all patients. patients treated by the University Hospital Multiprofessional Service for obese patients who are candidates for bariatric surgery. The collection took place from January 2014 to March 2016. A weight-dependent variable, used in the body mass index (BMI) and degree of obesity and as independent variables of sex, age, education, income, number of diseases, number of drugs and number of MLGP. The association was calculated using the Ro Spearman correlation and the chi-square test. Results: 102 patients were studied, mostly women (87\%), with a mean BMI of $45.9 \mathrm{~kg} / \mathrm{m} 2$ (min 32.56 - maximum $70.98 \mathrm{~kg} / \mathrm{m} 2 \mathrm{SD}=6.43$ ). The main comorbidities were systemic arterial hypertension (65.7\%) and osteoarticular disorders (39.2\%). The average number of drugs per patient was 4.3 and the most used class was for the renin-angiotensin system (67.3\%). MLGP corresponds to $10.4 \%$ of the drugs used and $27.4 \%$ of the patients use them. MLGP patients used an average of 5.8 medications and the most prevalent classes were betablocking agents (60.6\%), followed by medications used in diabetes (24.2\%). Atenolol and a glibenclamide were the most used MLGP. The mean BMI of patients who used more than one MLGP was $51 \mathrm{~kg} / \mathrm{m} 2$. Conclusion: There was no correlation between weight and the use of MLGP in this population. However, patients who used the MLGP combination had a higher BMI.
\end{abstract}

Keywords: obesity, drug therapy, weight gain, obesity management.

\section{Medicamentos que levam ao ganho de peso usados por pacientes acompanhados em serviço de cirurgia bariátrica e metabólica de um hospital universitário}

\begin{abstract}
Resumo
Objetivo: Verificar a associação entre peso e o uso de medicamentos que levam ao ganho de peso (MLGP) em uma população de obesos acompanhados no Sistema Único de Saúde. Métodos: Trata-se de um estudo seccional descritivo retrospectivo com dados dos prontuários de todos os pacientes atendidos por Serviço multiprofissional de Hospital Universitário para pacientes obesos candidatos a cirurgia bariátrica. A coleta ocorreu de janeiro de 2014 a março de 2016. A variável dependente foi o peso, caracterizado em índice de massa corporal (IMC) e graus de obesidade e as variáveis independentes foram sexo, idade, escolaridade, renda, número de doenças, número de medicamentos e número de MLGP. A associação foi calculada por meio da correlação de Ró Spearman e pelo teste do quiquadrado. Resultados: Foram estudados 102 pacientes, a maioria mulheres (87\%), com IMC médio de 45,9 kg/m2 (min 32,56- max $70,98 \mathrm{~kg} / \mathrm{m} 2 \mathrm{DP}=6,43)$. As principais comorbidades foram a hipertensão arterial sistêmica $(65,7 \%)$ e os distúrbios osteoarticulares (39,2\%). A média de medicamentos por paciente foi de 4,3 e a classe mais usada foi medicamentos para o sistema renina angiotensina (67,3\%). Os MLGP corresponderam a 10,4\% dos medicamentos usados e $27,4 \%$ dos pacientes faziam uso deles. Os pacientes com MLGP usaram me média 5,8 medicamentos e as classes mais prevalentes foram as dos agentes beta-bloqueadores (60,6\%), seguidos dos medicamentos usados na diabetes (24,2\%). O atenolol e a glibenclamida foram os MLGP mais usados. O IMC médio dos pacientes que usavam mais de um MLGP foi $51 \mathrm{~kg} / \mathrm{m} 2$. Conclusões: Não houve correlação entre peso e o uso de MLGP nessa população. Porém, pacientes que usavam associação de MLGP apresentaram IMC mais altos.
\end{abstract}

Palavras-chave: obesidade, tratamento farmacológico, ganho de peso, manejo da obesidade. 


\section{Introduction}

Obesity is a disease with multi-factorial origin and can be defined as the accumulation of generalized fat, which causes harm to health and which, due to its growth in recent decades, has been treated as a health problem ${ }^{1}$. Obesity is directly related to the emergence of health problems like systemic arterial hypertension $(\mathrm{SAH})$, diabetes, and dyslipidemia, among others, which decrease the quality of life of individuals, in addition to generating greater mortality ${ }^{2,3}$

According to the World Health Organization (WHO), obesity affects approximately $40 \%$ of the adult population and $30 \%$ of the child population ${ }^{4}$; there are 672 million obese adults and 164 million obese children and adolescents worldwide 5 . In Brazil, $19.8 \%$ of the population is obese, with a higher prevalence among women, and $55.7 \%$ of the Brazilians are overweight ${ }^{6}$.

It is estimated that around 80 thousand people die annually in Brazil from diseases related to obesity. The treatment of these diseases leads to a considerable increase in health spending to the country. The Public Health System (Sistema Único de Saúde, SUS) spent R\$25,404,454.87 on the treatment of obesity between 2008 and 2011, a figure which represents an increase of $R \$ 16,260,197.86$ in this period ${ }^{7}$

In this scenario, the demand for treatments for obesity and related diseases has intensified in recent years and, although pharmacotherapy is used to improve medical conditions, medications can be associated with a wide variety of adverse effects, including weight gain ${ }^{8}$.

Many drugs used to treat obesity-related comorbidities can influence weight gain or the exacerbation of weight gain in susceptible individuals ${ }^{9}$. The mechanisms involved in the effects on weight are poorly understood but may involve changes in food intake, energy expenditure, and even lipogenesis or adipogenesis ${ }^{10}$. The difficulty in weight loss or weight gain during the treatment of obesity is related to worse health results ${ }^{8}$, like higher mortality.

Given the above, the present study aimed to verify the association between weight and the use of weight-gaining medications (WGMs) in a population of obese patients monitored in an outpatient clinic of the Public Health System.

\section{Methods}

This is a cross-sectional and descriptive study that followed the recommendations of STROBE ${ }^{11}$ for reporting observational studies. The data were collected from the medical records of patients treated by the Bariatric and Metabolic Surgery Service of the University Hospital of Western Paraná (Serviço de Cirurgia Bariátrica e Metabólica do Hospital Universitário do Oeste do Paraná, SCBM-HUOP) in Cascavel-PR, Brazil. It is a multi-professional outpatient clinic for patients diagnosed with obesity and designated by the regional health department for the treatment, and when indicated to the bariatric surgery.

All the patients treated by the service from January 2014 to March 2016 were included in the study. The medications data came from pharmaceutical interviews, which were carried out individually. The patients were characterized according to gender, age, schooling, income, weight by the Body Mass Index (BMI), number of comorbidities, number of drugs in use, and number of weight-gaining medications (WGMs). The medications were also classified into the second and fifth levels from the Anatomical Therapeutical Chemical (ATC) Classification of the $\mathrm{WHO}^{11}$.

Schooling was classified as illiteracy, less than 5 years, 5 to 12 years, and over 12 years of study. Family income was classified as less than 3 minimum wages, 3 to 5 minimum wages, and more than 5 minimum wages. The BMI was calculated according to the following formula: $\mathrm{BMI}=$ Weight $/(\text { Height })^{2}$ and later classified in degrees of obesity according to the WHO ${ }^{12}$, Grade 1 (BMI 30-34.9 $\mathrm{kg} / \mathrm{m} 2$ ), Grade 2 (BMI $35-39.9 \mathrm{~kg} / \mathrm{m} 2$ ), and Grade 3 (BMI $\geq 40.0$ $\mathrm{kg} / \mathrm{m} 2)$.

For the classification of the WGMs, a list of drugs was built based on the 2016 Brazilian Obesity Guidelines ${ }^{9}$ and the 2013 Australian Guidelines for the clinical practice for overweight and obesity in adults, adolescents, and children ${ }^{13}$. The list of WGMs were composed of 21 drugs that were included in the guidelines, which there was scientific evidence of their participation in the weight gain of patients in treatment (amitriptyline, nortriptyline, clozapine, olanzapine, quetiapine, gabapentin, risperidone, lithium, valproate of sodium, chlorpromazine, anabolic steroids, prednisone, propranolol, atenolol, chlorpropramide, glibenclamide, glimepiride, glipizide, insulin, pioglitazone, and tolbutamide).

The data were collected and tabulated in an Excel $^{\circledR}$ spreadsheet and analyzed by $R$ software, version 3.3.114. The level of statistical significance was $5 \%(p<0.05)$, and the dependent variable was weight, characterized by BMI and degrees of obesity. The independent variables were gender, age, schooling, income, number of diseases, number of drugs, and number of WGMs. For the numerical variables, the association was calculated using Spearman's Rho correlation, which is employed to the variables without normal distribution; and the chi-square test was performed to the categorical variables.

The study was approved by the Research Ethics Committee of the State University of Western Paraná (Universidade Estadual do Oeste do Paraná, UNIOESTE), under opinion No. 1,180,202 of 2015.

\section{Results}

One hundred two patients were studied, mostly women (87\%) with a median age of 41 years old (min. 17- max. 69), with a mean BMI of $45.98 \mathrm{~kg} / \mathrm{m} 2$ (min. 32.56 - $\max .70 .98 ; \mathrm{SD}=6.43$ ), with five to twelve years of study (61.7\%), and an income equal to or less than 3 minimum wages $(61.7 \%)$. The main comorbidities found were systemic arterial hypertension (SAH) (65.7\%) and osteoarticular disorders (39.2\%) (Table 1).

The patients using WGMs corresponded to $27.4 \%$ of those surveyed, mostly $(86.7 \%)$ was women with a median age of 46.5 years old (min. 26 - max. 69), a mean BMI of $45.54 \mathrm{~kg} / \mathrm{m}^{2}$ (min. 35.2- max. 63.9; $S D=6.37)$, with 5 to 12 years of study $(60.7 \%)$, and an income equal or less than 3 minimum wages (71.4\%) (Table 2).

The mean number of diseases was $3.8(S D=2)$ per patient and $4.8(S D=1.8)$ in patients using WGMs. The association of comorbidities with obesity was found in $96.1 \%$ of the individuals studied, with $73.5 \%$ presenting more than three associated comorbidities. The patient who had more health problems apart 
Table 1. Characterization of the study population according to sociodemographic characteristics, diseases, and pharmacotherapy. Cascavel, Paraná-Brazil, 2016.

\begin{tabular}{|c|c|c|c|}
\hline Data & Obese patients & $\begin{array}{l}\text { Patients using weight-gaining } \\
\text { medication }\end{array}$ & $\mathrm{p}$ value \\
\hline Sociodemographic characteristics & $(N=102)$ & $(N=28)$ & \\
\hline \multicolumn{4}{|l|}{ Gender \% ( $n$ ) } \\
\hline Female & $87.2(89)$ & $85.7(24)$ & \multirow[t]{2}{*}{0.6702} \\
\hline Male & $12.8(13)$ & $14.3(4)$ & \\
\hline \multicolumn{4}{|l|}{ Age $\%(n)$} \\
\hline$<30$ years old & $8.8(9)$ & $7.1(2)$ & \multirow{3}{*}{0.0378} \\
\hline $30-50$ years old & $63.7(65)$ & $53.6(15)$ & \\
\hline$>50$ years old & $27.5(28)$ & $39.2(11)$ & \\
\hline \multicolumn{4}{|l|}{ Schooling \% (n) } \\
\hline Illiterate & $1.9(2)$ & - & \multirow{4}{*}{0.9452} \\
\hline$<5$ years of study & $23.5(24)$ & $35.7(10)$ & \\
\hline $5-12$ years of study & $61.8(63)$ & $60.7(17)$ & \\
\hline$>12$ years of study & $12.8(13)$ & $3.6(1)$ & \\
\hline \multicolumn{4}{|l|}{ Income in minimum wages ${ }^{1} \%(n)$} \\
\hline$<3$ & $61.8(63)$ & $71.4(20)$ & \multirow{5}{*}{0.9595} \\
\hline 3 to 5 & $26.5(27)$ & $25.0(7)$ & \\
\hline$>5$ & $11.7(12)$ & $3.6(1)$ & \\
\hline Condition profile & $(N=379)$ & $(N=136)$ & \\
\hline Media (SD) of comorbidities/patient & $3.8(2.0)$ & $4.8(1.8)$ & \\
\hline \multicolumn{4}{|l|}{ Condition types \% (n) } \\
\hline Systemic arterial hypertension & $65.7(67)$ & $89.3(25)$ & \multirow{14}{*}{0.1265} \\
\hline Osteoarticular disorders & $39.2(40)$ & $57.1(16)$ & \\
\hline Gastric disorders & $39.2(40)$ & $39.3(11)$ & \\
\hline Anxiety & $35.3(36)$ & $42.8(12)$ & \\
\hline Diabetes & $34.3(35)$ & $53.6(15)$ & \\
\hline Dyslipidemia & $34.3(35)$ & $39.3(11)$ & \\
\hline Respiratory disorders & $27.4(28)$ & $21.4(6)$ & \\
\hline Depression & $25.5(26)$ & $28.6(8)$ & \\
\hline Steatosis & $18.6(19)$ & $28.6(8)$ & \\
\hline Hypothyroidism & $11.8(12)$ & $17.8(5)$ & \\
\hline Heart disease & $6.9(7)$ & $14.3(4)$ & \\
\hline Renal problem & $2.0(2)$ & - & \\
\hline Others & $31.4(32)$ & $39.3(11)$ & \\
\hline Pharmacotherapy & $(N=394)$ & $(N=165)$ & \\
\hline \multicolumn{4}{|l|}{ Medications } \\
\hline Patients in use \% (n) & $89.2(91.0)$ & $100.0(28.0)$ & \multirow[t]{2}{*}{0.3439} \\
\hline Mean number per patient (SD) & $4.3(2.7)$ & $5.9(2.4)$ & \\
\hline \multicolumn{4}{|l|}{ Weight-gaining medications } \\
\hline Patients in use $\%(n)$ & $27.4(28.0)$ & $100.0(28.0)$ & \multirow[t]{2}{*}{0.2275} \\
\hline Mean number per patient (SD) & $0.3(0.1)$ & $1.2(0.5)$ & \\
\hline
\end{tabular}

${ }^{1}$ Mean minimum wage in the study period: USD 255.50

from obesity reported eleven pathologies. A negative correlation was found between $\mathrm{BMI}$ and age. The other associations were not significant (Table 1).

The patients used 394 drugs with a mean of 4.3 per patient and 5.9 in patients using WGMs. There were 77 different drugs, and the most used classes were the agents that act on the reninangiotensin system (CO9) (56.9\%), followed by diuretics (C03) (50\%), and the most commonly found medication was omeprazole (38.2\%) (Table 2).

Thirty-three WGMs (8 different drugs) were found, corresponding to $8.8 \%$ of the total drugs, which $60.6 \%$ were beta-blocking agents
(C07), 24.2\% were drugs used in diabetes (A10), 9.1\% were psychoanaleptics (N06), and 6.1\% corresponded to others. The most used WGM was atenolol (45.5\%) followed by glibenclamide (15.1\%), propranolol (12.1\%), insulin (9.1\%), nortriptyline (6.1\%), and others (12.1\%).

The association of WGMs was found in four patients (14.3\%), two of them using 3 WGMs, and the other two using 2. The mean $\mathrm{BMI}$ of the patients who used more than one WGM was $51 \mathrm{~kg} / \mathrm{m}^{2}$ (result presented only in the text). 
Table 2. Medications used by SCBM-HUOP patients classified according to the $2^{\text {nd }}$ and $5^{\text {th }}$ levels of the ATC in Cascavel, Paraná-Brazil, 2016.

\begin{tabular}{|c|c|c|c|}
\hline Data & $\begin{array}{l}\text { Patients in use } \\
(\mathrm{N}=91) \\
\%(\mathrm{n})\end{array}$ & $\begin{array}{l}\text { Total medications } \\
(\mathrm{N}=394) \\
\%(\mathrm{n})\end{array}$ & Literature findings that support weight gain \\
\hline \multicolumn{4}{|l|}{ 2nd level of the ATC classification } \\
\hline C09 - Agents acting on the renin-angiotensin system & $63.7(58)$ & $14.7(58)$ & \\
\hline C03- Diuretics & $56.0(51)$ & $12.9(51)$ & \\
\hline A02 - Medications for acid-related disorders & $43.9(40)$ & $10.1(40)$ & \\
\hline A10 - Medications for diabetes & $43.9(40)$ & $10.1(40)$ & $\begin{array}{l}\text { [Pioglitazone (2-3.9 } \mathrm{kg}) \text {, rosiglitazone }(1.2-5.3 \\
\mathrm{kg}) \text {, chlorpropamide }(2.6-5.3 \mathrm{~kg}) \text {, tolbutamide } \\
(1.6-2.8 \mathrm{~kg}) \text {, and insulin }(0.4-4.8 \mathrm{~kg})]^{8,15} \text {. }\end{array}$ \\
\hline N06 - Psychoanaleptics & $35.2(32)$ & $8.1(32)$ & $\begin{array}{l}\text { Highlight for antidepressants: [amitriptyline }(0.4- \\
7.3 \mathrm{~kg}) \text {, nortriptyline }(0.3-4.1 \mathrm{~kg}) \text {, citalopram }(-0.1 \\
\text { to }+7.1 \mathrm{~kg})]^{8,15} \text {. }\end{array}$ \\
\hline C10 - Lipid-modifying agents & $26.4(24)$ & $6.1(24)$ & \\
\hline C07 - Beta blocking agent & $24.2(22)$ & $5.6(22)$ & $\begin{array}{l}\text { [Atenolol }(-0.5 \text { to }+3.4 \mathrm{~kg}) \text {, propranolol }(-0.5 \text { to } \\
+2.3 \mathrm{~kg})]^{8,15} \text {. }\end{array}$ \\
\hline G03 - Sex hormones and system modulators & $18.7(17)$ & $4.3(17)$ & \\
\hline B01 - Antithrombotic agents & $12.1(11)$ & $2.8(11)$ & \\
\hline C08 - Calcium channel blockers & $11.0(10)$ & $2.3(10)$ & \\
\hline H03 - Thyroid therapy & $11.0(10)$ & $2.3(10)$ & \\
\hline Other classes & $86.8(79)$ & $20.0(79)$ & $\begin{array}{l}\text { [N05 Psycholeptics - antipsychotics and mood } \\
\text { stabilizers: chlorpromazine (gain of 0.6-15.9 kg), } \\
\text { clozapine (gain of } 4.5-16.2 \mathrm{~kg}) \text {, olanzapine (gain } \\
\text { of } 3.6-10.2 \mathrm{~kg} \text { ) and lithium (gain of } 1.1-9.9 \mathrm{~kg})] \\
8,15 \text {. Corticosteroids (use } \geq 3 \text { months): [prednisone } \\
(1.7-5.8 \mathrm{~kg}) \text {, prednisolone (1.5-4.4 kg), and } \\
\text { cortisone }(1.5-8.4 \mathrm{~kg})]^{8} \text {. }\end{array}$ \\
\hline \multicolumn{4}{|l|}{ 5th level of the ATC classification } \\
\hline Omeprazole & $42.8(39)$ & $9.9(39)$ & \\
\hline Hydrochlorothiazide & $36.3(33)$ & $8.4(33)$ & \\
\hline Losartan & $34.1(31)$ & $7.9(31)$ & \\
\hline Metformin & $30.8(28)$ & $7.1(28)$ & \\
\hline Simvastatin & $25.3(23)$ & $5.8(23)$ & \\
\hline Fluoxetine & $22.0(20)$ & $5.1(20)$ & \\
\hline Contraceptive & $18.7(17)$ & $4.3(17)$ & \\
\hline Atenolol & $17.6(16)$ & $4.1(16)$ & [Atenolol $(-0.5$ to $+3.4 \mathrm{~kg}$ ] 8,15 \\
\hline Enalapril & $17.6(16)$ & $4.1(16)$ & \\
\hline Other medications & $9.9(9)$ & $43.4(171)$ & \\
\hline
\end{tabular}

\section{Discussion}

The study found a negative correlation between BMI and age, showing that younger patients had a higher BMI. The mean BMI $\left(45.98 \mathrm{~kg} / \mathrm{m}^{2}\right)$ is similar to the results of SUS outpatients ${ }^{1}(45.75 \mathrm{~kg} /$ $\mathrm{m}^{2}$, but higher means were observed in other studies ${ }^{3,2}$. This result characterizes the studied patients as an obese young population with a high BMI in search of a complex health treatment: bariatric surgery ${ }^{16}$. In Brazil and worldwide, the growth of obesity among children and young people has been documented by populationbased surveys ${ }^{5,17}$. Several years of exposure to excess and weight gain have led this group to enter adult life already obese and with a high $\mathrm{BMI}^{18}$.

Women around 40 years of age are the majority of the patients studied and users of WGMs, a reality in agreement with the more significant presence of women among the obese population in Brazil $^{2,19,20}$ and the world ${ }^{5}$. The obesity rate of the Brazilian population went from 11.8\% to 19.8\% between 2006 and 2018, with a higher prevalence in women (20.7\%) (men 18.7\%), between
35 and 65 years old ${ }^{6}$. In Brazil, in addition to the female gender, obesity is also associated with lower income and low schooling ${ }^{6,20}$. This and other studies show lower-income and low schooling as a characteristic of obese patients $3,19,20$.

The main comorbidity found was $\mathrm{SAH}$, the most prevalent disease in obese patients ${ }^{1,2,5,9}$. The more prolonged and severe obesity, the higher the propensity of the patient to develop arterial hypertension ${ }^{21}$. Diabetes was the fifth most prevalent comorbidity, a result similar to other studies ${ }^{17,20}$. The management of the obese patient becomes much more complicated when there are multiple associated diseases ${ }^{22}$, mainly diabetes and psychiatric diseases, and their treatments that lead to weight gain ${ }^{8}$.

The mean number of 4.3 drugs demonstrates the polypharmacy that is common in patients with obesity ${ }^{16}$. Renin-angiotensin system inhibitors and diuretics were the most used drug classes in this study and also the most prevalent in pre- and post-bariatric surgery patients ${ }^{23}$. Such classes are the frontline in the treatment of $\mathrm{SAH}^{8}$, the most present comorbidity. 
The WGMs were used by $27.4 \%$ of the patients, and, to date, no studies were found in Brazil which evaluate the use of these drugs to comparison purposes. These patients used, on average (5.9), more medications than the others, and when there was the association of more than one WGM, the mean BMI went from 45.5 to $51 \mathrm{~kg} / \mathrm{m}^{2}$, signaling the effect of these drugs on the weight gain of the patients ${ }^{8}$.

Among the WGMs, the most prescribed classes (beta-blockers and drugs used in diabetes) deserve attention to their obesogenic effect and highly prevalent drugs worldwide ${ }^{8}$. The most commonly used medication in general was omeprazole and its use may be associated with gastric symptoms, the third health complaint most cited by the patients studied. Gastroesophageal reflux is a prevalent symptom in obese patients ${ }^{24}$ and also for its use, although controversial and not recommended in the long term ${ }^{25}$, to decrease gastric discomfort in patients using various medications.

The main limitations of this article are related to the cross-sectional design, in which the temporality and causality is compromised, to the case series that included a small number of patients from a single service, which affects the representativeness of the results, and to the measurements of weight, measures, and BMI that were made by the service, which can lead to measurement and classification errors. However, it carries the qualities of not having any studies on the use of WGMs in Brazil, that the studied patients belong exclusively to the SUS and are attended in an exclusive multidisciplinary clinic for the care of obese patients, and of adding data to the discussion about care with the choice of medications to treat comorbidities in the obese patient.

Due to the obesogenic effects of the WGMs and to the difficulties encountered for long-term weight loss, the evaluation of the weight gain potential associated with drug treatment has particular importance. The recommendation ${ }^{8,9,13}$ is that every time a weight-gaining medication needs to be prescribed, it must be accompanied by others that lead to weight loss or which, at least, do not alter weight with its use.

\section{Conclusion}

Approximately one-third of the patients studied were using WGMs, a considerable proportion of obese patients exposed to medication-related weight gain. There was no correlation between weight gain and the use of WGMs in this population. However, patients with an association of WGMs had a higher BMI, signaling the potential effect of these drugs on weight gain and the need for clinical evaluation. Physicians and pharmacists need to be aware of replacing, when possible, WGMS with drugs that do not affect weight, especially in individuals who are already overweight or obese.

\section{Funding sources}

The authors declare that the research did not receive funding for its realization.

\section{Collaborators}

LFAS, LLS, ACFA participated in the design of the project, data analysis and interpretation, writing of the article, and final approval of the version to be published. PVSM participated in the design and coordination of the project, data analysis and interpretation, writing of the article, relevant critical review of the intellectual content, and final approval of the version to be published. All the authors assume responsibility for all the information on the work, ensuring the accuracy and integrity of any of its parts.

\section{Conflict of interest statement}

The authors have no conflict of interest to declare in relation to this article.

\section{References}

1. Quesada K, Detregiachi CRP, Barbalho SM, et al. Perfil socioeconômico e antropométrico de candidatas à cirurgia bariátrica pelo sistema único de saúde. Revista Saúde e Pesquisa. 2015;8(3):431-438.

2. Oliveira RMM, Passos XS, Marques MS. Perfil do indivíduo candidato à cirurgia bariátrica no Hospital Geral de GoiâniaGO. J Health Sci Inst. 2013;31(2):172-5.

3. Rodrigues APS, Silveira EA. Correlação e associação de renda e escolaridade com condições de saúde e nutrição em obesos graves. Ciênc. saúde coletiva. 2015; 20(1):165-174.

4. World Health Organization (WHO). Global health Observatory Data. Overweight and Obesity. 2016. Available from https:// www.who.int/gho/ncd/risk_factors/overweight_text/en/. Accessed on March 4, 2020.

5. NCD Risk Factor Collaboration. Trends in adult body-mass index in 200 countries from 1975 to 2014: a pooled analysis of 1698 population-based measurement studies with $19 \cdot 2$ million participants. Lancet. 2016; 387(10026):1377-96.

6. Brasil. Ministério da Saúde. Vigitel Brasil 2018: vigilância de fatores de risco e proteção para doenças crônicas por inquérito telefônico. Available from https://portalarquivos2.saude. gov.br/images/pdf/2019/julho/25/vigitel-brasil-2018.pdf. Accessed on March 4, 2020.

7. Mazzoccante RP, Moraes JFVN, Campbell CSG. Gastos públicos diretos com a obesidade e doenças associadas no Brasil. Rev. Ciênc. Méd. 2012;21(1-6):25-34.

8. Wharton S, Raiber L, Serodio KJ, et al. Medications that cause weight gain and alternatives in Canada: A narrative review. Diabetes, Metab Syndr Obes Targets Ther. 2018;11:427-38.

9. Associação Brasileira para o Estudo da Obesidade e da Síndrome Metabólica ABESO. Diretrizes brasileiras de obesidade. 2016 Available from http://www.abeso.org.br/uploads/ downloads/92/57fccc403e5da.pdf. Accessed on 04/03/2020.

10. Von Elm E, Altman DG, Egger M, et al. The Strengthening the Reporting of Observational Studies in Epidemiology (STROBE) Statement: Guidelines for reporting observational studies. Int J Surg. 2014;12(12):1495-9.

11. WHO. Collaborating Centre for Drug Statistics Methodology. Anatomical Therapeutic Chemical ATC/DDD Index 2020. Available from https://www.whocc.no/atc ddd index/. Accessed on March 4, 2020.

12. WHO. Global recommendations on physical activity for health. 
2010. Available from https://apps.who.int/iris/bitstream/han dle/10665/44399/9789241599979_eng.pdf?sequence=1. Accessed on March 4, 2020

13. National Health and Medical Research Council. Clinical practice guidelines for the management of overweight and obesity in adults, adolescents and children in Australia. 2013. Available from: https://www.nhmrc.gov.au/_files_nhmrc/ publications/attachments/n57_obesity_guidelines_140630. pdf. Accessed on March 4, 2020.

14. R Foundation for Statistical Computing. R Development Core Team (2016) R: A language and environment for statistical computing. Available from https://www.r-project.org/. Accessed on March 4, 2020.

15. Leslie WS, Hankey CR, Lean ME. Weight gain as an adverse effect of some commonly prescribed drugs: a systematic review. 2007.QMJ;100(7):395-404.

16. Carvalho CW, Dani C, Kaminski RS et al. Perfil farmacoterapêutico de pacientes obesos pré-cirurgia bariátrica. Rev Bras Farm Hosp Serv Saude. 2014;5(3):6-11.

17. De Souza CC, Peixoto MDRG, Mendonça KL, et al. Excesso de peso e fatores associados em adolescentes de uma capital Brasileira. Rev Bras Epidemiol. 2017;20(2):260-73.

18. Ward ZJ, Long MW, Resch SC, et al. Simulation of growth trajectories of childhood obesity into adulthood. N Engl J Med. 2017;377(22):2145-53.

19. Lima LP, Sampaio HA. Caracterização socioeconômica, antropométrica e alimentar de obesos graves. Ciênc. saúde coletiva. 2007;12(4):1011-1020.

20. Vedana EHB, Peres MA, Neves J, et al. Prevalência de obesidade e fatores potencialmente causais em adultos em região do sul do Brasil. Arq Bras Endocrinol Metab. 2008 ;52(7):11561162.

21. Costa ACC, Ivo ML, Cantero WB et al. Ocorrência de hipertensão arterial em pacientes obesos. Rev enferm UFPE. 2013;7(7):4712-7.

22. Medici V, McClave SA, Miller KR. Common Medications Which Lead to Unintended Alterations in Weight Gain or Organ Lipotoxicity. Gastroenterol Rep. 2016;18(1):2.

23. Kovaleski ES, Schroeder H, Krause M, et al. Pharmacotherapeutic profile of obese patients during the postoperative period after bariatric surgery. J. vasc. bras. 2016;15(3):182188.

24. Richter JE, Rubenstein JH. Presentation and Epidemiology of Gastroesophageal Reflux Disease. Gastroenterology. 2018 ;154(2):267-76.

25. Scarpignato C, Gatta L, Zullo A, et al. Effective and safe proton pump inhibitor therapy in acid-related diseases - A position paper addressing benefits and potential harms of acid suppression. BMC Med. 2016;14(1):179. 